\title{
Feeding a diet with corn distillers grain with solubles to dairy cows alters manure characteristics and ammonia and hydrogen sulfide emissions from manure
}

\author{
C. Lee, ${ }^{*}$ ๑ D. L. Morris, $\odot$ K. M. Lefever, and P. A. Dieter $\odot$
}

Department of Animal Sciences, Ohio Agricultural Research and Development Center, The Ohio State University, Wooster 44691

\begin{abstract}
The objective of the experiment was to examine effects of a diet containing a high concentration $(28.8 \%$ dry matter basis) of corn distillers grain with solubles on manure characteristics and $\mathrm{NH}_{3}$ and $\mathrm{H}_{2} \mathrm{~S}$ emissions from dairy cow manure. Eighteen cows were blocked by parity and days in milk, and cows in each block were assigned to the following treatments: the control diet $(\mathrm{CON})$ or $\mathrm{CON}$ with distillers grains with solubles at $28.8 \%$ (dry matter basis) replacing mainly soybean meal (DG). The experiment was conducted for $11 \mathrm{wk}$, and feces and urine from individual cows were collected over $3 \mathrm{~d}$ in wk 11 (a total of 8 spot samples per cow). Fecal or urine samples were composited by cow, and the composite feces and urine were analyzed for indigestible neutral detergent fiber and creatinine concentration, respectively, for individual cows to estimate total fecal and urine outputs. Immediately before the manure incubation, composited feces and urine were sampled to determine manure characteristics. Manure was reconstituted according to daily fecal and urine excretion estimated for individual cows. Individual manures were incubated using a continuous air flux multichamber system over $10 \mathrm{~d}$ to measure $\mathrm{NH}_{3}$ and $\mathrm{H}_{2} \mathrm{~S}$ emissions. All data from 18 manures were analyzed using the Mixed procedure of SAS (SAS Institute Inc., Cary, NC). The ratio of feces to urine and the contents of manure total and volatile solids were not different among treatments. Urine from DG had lower $\mathrm{pH}$ and DG manure had lower $\mathrm{N}$ content and greater $\mathrm{S}$ content compared with CON. During the 10-d incubation, $\mathrm{NH}_{3}$ emission was considerably less for DG versus CON. The emission of $\mathrm{H}_{2} \mathrm{~S}$ over $10 \mathrm{~d}$ for $\mathrm{DG}$ was greater compared with that for CON. After the incubation, manure $\mathrm{pH}$ and $\mathrm{N}$ and $\mathrm{S}$ concentrations were greater for $\mathrm{DG}$ versus CON. In conclusion, manure from cows fed a high-DG diet decreased urinary $\mathrm{N}$ contribution to manure $\mathrm{N}$ and
\end{abstract}

Received August 30, 2019.

Accepted November 5, 2019.

*Corresponding author: lee.7502@osu.edu lowered urine $\mathrm{pH}$, which were the factors that caused the decrease in $\mathrm{NH}_{3}$ emission from DG manure. However, the DG diet increased dietary S concentration and increased $\mathrm{S}$ excretion in urine and feces. This increased $\mathrm{H}_{2} \mathrm{~S}$ emission from DG manure during the 10-d manure incubation.

Key words: corn distillers grains with solubles, manure, ammonia, hydrogen sulfide

\section{INTRODUCTION}

An increase in ethanol production has resulted in an increase in production of dry corn distillers grains with solubles (DDGS). Because of its nutritional values (i.e., high protein, fat, and fiber) and its cheap price relative to other high-protein feeds (e.g., soybean meal; SBM), DDGS has been used as a feed for livestock animals. In dairy cows, studies with distillers grains have focused on its nutritional values and production responses (Schingoethe et al., 2009). In terms of production, it is clear that high inclusion of DDGS in a ration (e.g., $30 \%$ in dietary DM) increases risk of milk fat depression (Ramirez-Ramirez et al., 2016; Morris et al., 2018a). However, fewer studies have looked at environmental impacts of feeding diets high in DDGS to dairy cows.

Improving the sustainability of dairy operations is a current primary goal in the US dairy industry, and lessening environmental impacts from dairy production is one of the critical tasks to improve sustainability (https: //nifa.usda.gov/program/sustainable-agriculture -program). Therefore, the environmental impact as well as production responses should be considered when feedstuffs are evaluated to determine their nutritional values and inclusion rates in dairy rations. In terms of environmental impact, DDGS has been studied for its effects on enteric methane production in dairy cows (Benchaar et al., 2013; Foth et al., 2015). However, limited studies have been conducted with DDGS to determine other environmental impacts such as nutrient excretion and nutrient losses from manure (e.g., gas emissions). Manure is not a waste but good fertilizer for 
crops. However, when managed at farms or applied to the field improperly, it can negatively affect air (emissions of ammonia and hydrogen sulfide), water ( $\mathrm{N}$ and $\mathrm{P}$ leaching and runoff), and soil quality (acidification; Aillery et al., 2005).

Ammonia and hydrogen sulfide emitted from manure can be an environmental concern because ammonia volatilization is not only a loss of manure $\mathrm{N}$ but also negatively contributes to the environment such as air quality (formation of particulate matter $<2.5 \mu \mathrm{m}$ ), farm odor, soil acidification, and water quality ( $\mathrm{N}$ leaching and runoff; NRC, 2003). Hydrogen sulfide emission from manure has been less studied compared with ammonia, especially in dairy cows, so the degree of $\mathrm{H}_{2} \mathrm{~S}$ emitted from dairy manure is not known. Hydrogen sulfide is a dangerous gas causing potential human and animal health concerns (Costigan, 2003): serious injury or death at $>500 \mathrm{ppm}$, injury with chronic exposure at $10 \mathrm{ppm}$. When DDGS replaces SBM in a dairy ration, this may alter manure characteristics and $\mathrm{NH}_{3}$ and $\mathrm{H}_{2} \mathrm{~S}$ emissions from manure. The content of RDP and RUP is different between DDGS and SBM (Mjoun et al., 2010; Maxin et al., 2013). Therefore, when SBM is replaced fully with DDGS, dietary RDP and RUP will change, and this could be a factor that shifts $\mathrm{N}$ excretion from urine to feces (Hristov et al., 2011; Morris et al., 2018b) and may decrease $\mathrm{NH}_{3}$ emission from manure (Lee et al., 2011). Hydrogen sulfide emission from manure may increase when a DDGS diet is fed compared with a SBM diet because high $\mathrm{S}$ content in DDGS increases dietary $\mathrm{S}$ content and increases fecal and urine $\mathrm{S}$ concentrations (i.e., manure $\mathrm{S}$ concentration; Morris et al., 2018b).

The objective of this study was to examine manure characteristics ( $\mathrm{N}$ of feces, urine, and manure) altered by feeding a high-DDGS diet and its effects on $\mathrm{NH}_{3}$ and $\mathrm{H}_{2} \mathrm{~S}$ emissions from manure. Our hypotheses were (1) $\mathrm{NH}_{3}$ emissions from manure of cows fed a DDGS diet will be decreased compared with cows fed a SBM diet because of a shift in $\mathrm{N}$ excretion from urine to feces and (2) because manure of cows fed a DDGS diet versus a SBM diet contains greater $\mathrm{S}, \mathrm{H}_{2} \mathrm{~S}$ emissions will be greater.

\section{MATERIALS AND METHODS}

\section{Animals and Treatments}

All procedures in this project that involved animals were approved by The Ohio State University Institutional Animal Care and Use Committee (IACUC 2016A00000042).

This experiment was part of a larger experiment, and details about the cows used and experimental design and procedures were reported in our companion papers (Morris et al., 2018a,b). Briefly, an animal experiment was conducted in a randomized complete block design. A total of 36 Holstein cows (average \pm SD; DIM, 80 \pm 31 ; BW, $675 \pm 74 \mathrm{~kg}$ ) were randomly assigned to 3 dietary treatments (i.e., total of 12 blocks and 3 cows per block): CON, a control diet containing SBM as a main protein feed ingredient; DG, a diet containing reduced-fat corn distillers grain with solubles at $28.8 \%$ (DM basis); and the DG diet supplemented with monensin $(20 \mathrm{mg} / \mathrm{kg}$ of DM; Rumensin, Elanco Animal Health, Greenfield, IN). In the current study only cows fed the CON and DG diets were used to determine manure characteristics and gas emissions from manure. The CON diet consisted of corn silage ( $41.6 \%$ on a DM basis), alfalfa silage $(9.7 \%)$, alfalfa hay $(5.0 \%)$, corn grain (12.9\%), SBM (15.1\%), soyhulls (12.3\%), supplemental fat (1.34\%; Energy booster; Milk Specialties, Eden Prairie, MN), and minerals and vitamins. For the DG diet, DG replaced SBM, soybean hulls, fat source, and supplemental phosphorus (Morris et al., 2018a). The chemical composition of CON and DG was essentially the same (DM basis; CP, $17.6 \%$; NDF, $30.5 \%$, crude fat, $\left.4.5 \% ; \mathrm{NE}_{\mathrm{L}}, 1.57 \mathrm{Mcal} / \mathrm{kg}\right)$ except for $\mathrm{P}(0.36$ and $0.48 \%$, respectively) and $\mathrm{S}(0.21$ and $0.41 \%$, respectively). The experiment lasted for a total of $12 \mathrm{wk}$ (1-wk covariate, 2 -wk diet adaptation, and 9-wk experimental period). All diets were prepared once a day in the morning and fed to cows around $0500 \mathrm{~h}$. The diets were prepared as TMR and fed for ad libitum intake (5 to $10 \%$ of refusal) with free access to water.

\section{Sample Collection and Measurement}

Spot urine and feces were collected in wk 12 (the last week of the experimental period). Spot feces and urine were collected every $9 \mathrm{~h}$ over $3 \mathrm{~d}$ to have a total of 8 spot fecal and urine samples, representing every 3 $\mathrm{h}$ in a 24-h cycle (i.e., 0900 and $1800 \mathrm{~h}$ on d 1, 0300, 1200 , and $2100 \mathrm{~h}$ on d 2, and 0600, 1500, and $2400 \mathrm{~h}$ on d 3). Spot fecal samples (about 200 g per sample) were collected from the rectum, composited by cow, and frozen at $-20^{\circ} \mathrm{C}$. Spot urine samples (about 150 $\mathrm{mL}$ per sample) were collected by massaging the vulva. The samples were composited by cow (about a total of $1.2 \mathrm{~kg}$ ) and frozen at $-20^{\circ} \mathrm{C}$. Before freezing the composite urine samples, a subsample was taken and acidified with $2 \mathrm{M} \mathrm{HCl}$ for chemical analyses.

The composite fecal samples were subsampled, and the subsample was dried at $55^{\circ} \mathrm{C}$ and ground (Wiley mill; Arthur A. Thomas Co., Philadelphia, PA) through a 1-mm sieve. The ground samples were analyzed for $\mathrm{DM}$ at $100^{\circ} \mathrm{C}$ for $24 \mathrm{~h}$ and $\mathrm{OM}$ (method 942.05, AOAC International, 2000). The samples were also analyzed 
for total $\mathrm{N}$ using a combustion method (Elemental Analyzer; Flash 2000; Thermo Fisher Scientific, Waltham, MA) after pulverizing. Total S concentration in fecal DM was determined using inductively coupled plasma emission spectroscopy after microwave digestion with nitric acid (Isaac and Johnson, 1985). The composite fecal samples and feed and refusal samples collected during the sampling week were analyzed for indigestible NDF according to Huhtanen et al. (1994) except filter bags with a $25-\mu \mathrm{m}$ pore size (Ankom Technology Corp., Macedon, NY) were used for the ruminal incubation. The concentrations of indigestible NDF were used to estimate fecal outputs of individual cows.

Acidified composite urine samples were analyzed for total N (Morris et al., 2019) and S using inductively coupled plasma emission spectroscopy. Urinary creatinine concentrations were assayed for individual cows (kit 500701; Cayman Chemical, Ann Arbor, MI), and these were used to estimate urine outputs of individual cows according to Valadares et al. (1999) assuming a creatinine excretion rate of $29.0 \mathrm{mg} / \mathrm{kg}$ of BW (Tebbe and Weiss, 2018). The BW of individual cows were measured on 2 consecutive days during the sample collection.

\section{Manure Characteristics and Incubation}

For manure incubation, 9 blocks of cows out of 12 blocks were randomly selected (i.e., $\mathrm{n}=9$ per treatment). Feces and urine for individual cows were thawed right before the incubation, and feces (Van Baale et al., 2004) and urine were measured for $\mathrm{pH}$. Manures were reconstituted for individual cows according to the ratio of feces to urine determined previously [i.e., the estimated outputs of feces (DM and indigestible $\mathrm{NDF}$ ) and urine (creatinine)]. Total $\mathrm{N}$ and $\mathrm{S}$ were determined using $\mathrm{N}$ and $\mathrm{S}$ concentrations of feces and urine, respectively, and the reconstitution ratio of feces to urine. After reconstituting manure, a subsample (50 g per sample) was collected to determine the content of TS (i.e., DM) and volatile solids (VS; i.e., OM) as described for feces.

Manure incubation lasted for $10 \mathrm{~d}$ in a continuous air flux multichamber system. This system was developed initially by Wheeler et al. (2011) and used in this experiment with few exceptions. Briefly, the system included a total of 9 manure chambers (i.e., 1 blank chamber (no manure) and 8 chambers to incubate manures). In this experiment, 7 chambers ( 1 blank and 6 manure chambers) were used at each incubation (total of 3 incubations and 6 manures per incubation). Manures of cows in the same block were incubated together. For example, the first incubation was conducted with manures of cows in blocks 1 to 3 (6 manures) followed by manures from blocks 4 to 6 and then blocks 7 to 9. The capacity of each chamber is $17.5 \mathrm{~L}$, and the amount of manure incubated for each chamber was 2 $\mathrm{kg}$ with $5 \mathrm{~L} / \mathrm{min}$ air flow. The air generated from the pumps (DDL 15-101, Gast Manufacturing Inc., Benton Harbor, MI) is controlled by flow meters (VFB-67; Dwyer Instruments Inc., Michigan City, IN) for individual chambers. When manure is placed in the chamber, the chamber is closed (sealed) with a lid. The lid of the chamber has an inlet for air in and an outlet for air out through which air from the pump flows in, flushes the chamber, and exits the chamber. The outlet of the chamber is connected to exhaust via tubing (Teflonlined PVC with 0.32-mm inside diameter and 0.64-mm outside diameter; Tygon SE-200 Saint Gobain, Akron, $\mathrm{OH})$. A sampling line $(0.16-\mathrm{mm}$ inside diameter and 0.32 -mm outside diameter) from the exhaust tubing is connected to a diaphragm sampling pump (KPM27H; Koge Electronics Co. Ltd., Taipei, Taiwan). The sampling pump delivers the exhaust air containing gases from manure into the sampling bag (12-L multilayer, foil gas sampling bag, Restek, Bellefonte, PA) according to the sampling schedule controlled by an automatic sampling system (Arduino UNO; https://www.arduino .cc). The sampling schedule used in this experiment was that all the sampling pumps for chambers were turned on to sample gases for $30 \mathrm{~s}$ every 30 min over 24 $\mathrm{h}$. The sampling bags were replaced every $24 \mathrm{~h}$ during the experiment (i.e., 10-d incubation).

Gas samples collected over $24 \mathrm{~h}$ were analyzed for $\mathrm{NH}_{3}$ using a photoacoustic gas analyzer (detection range, 0.1 to 5,000 ppm; Gasera one, Gasera Ltd., Turku, Finland) and $\mathrm{H}_{2} \mathrm{~S}$ concentrations (detection range, $3 \mathrm{ppb}$ to $10 \mathrm{ppm}$ of $\mathrm{H}_{2} \mathrm{~S}$; Jerome J605; Arizona Instrument LLC, Chandler, AZ). Gas production from manure was determined using the following equations with an example of $\mathrm{NH}_{3}$ :

$$
\begin{gathered}
\mathrm{g} \text { of } \mathrm{NH}_{3} / \mathrm{kg} \text { of manure per } \mathrm{h}(A)= \\
{\left[\mathrm{NH}_{3} \text { concentration }(\mathrm{ppm})-\text { blank } \mathrm{NH}_{3}\right.} \\
\text { concentration }(\mathrm{ppm})] \times \text { air flow }(\mathrm{L} / \mathrm{min}) \\
\times \text { density }\left(0.769 \mathrm{~g} \text { of } \mathrm{NH}_{3} / \mathrm{L}\right. \text { at standard } \\
\text { temperature and pressure }) \times 60 \mathrm{~min} \div 2, \\
\mathrm{~g} \text { of } \mathrm{NH}_{3} / \text { cow per d }(B)=A \times 24 \times \text { estimated } \\
\text { daily manure output, and } \\
\text { Cumulative g of } \mathrm{NH}_{3} / \text { cow }=\sum_{i=1}^{10} B,
\end{gathered}
$$

where the final value was divided by 2 to express the emission per kilogram of manure $(2 \mathrm{~kg}$ of manure was 
incubated) in Equation 1, daily manure output was estimated using estimated daily fecal and urine outputs for individual cows in Equation 2, and $i$ indicates day (i.e., d 0 to 10) in Equation 3.

After the 10-d incubation, all the chambers were opened and mixed well to take 3 subsamples. The first sample was analyzed for $\mathrm{pH}$. The second sample was assayed for the content of TS (DM) and VS (OM) as described for feces. The third samples were acidified with $2 \mathrm{M} \mathrm{HCl}$ and freeze dried to determine total $\mathrm{N}$ and $\mathrm{S}$ concentrations. The analytical methods used here were the same as described previously for feces and manure.

\section{Statistical Analyses}

All data were analyzed using the Mixed procedure of SAS (version 9.4, SAS Institute Inc., Cary, NC). Data of BW, fecal and urine composition, and initial manure characteristics were analyzed using a model with block and block by dietary treatment as random effects and dietary treatment as a fixed effect. For data of manure characteristics after incubations, a similar model was used except that block, block by dietary treatment, and chamber within block were used as random effects. This model was modified to analyze gas emission rate ( $\mathrm{g}$ of $\mathrm{NH}_{3}$ or mg of $\mathrm{H}_{2} \mathrm{~S}$ per cow hourly), where time and interaction of treatment by time were added as fixed effects and repeated measures for time were included. Cumulative gas emissions over $10 \mathrm{~d}$ were analyzed with the same model without day effect. Significant differences among treatments were declared at $P \leq 0.05$. Differences at $0.05<P \leq 0.10$ were considered a trend toward significance.

\section{RESULTS}

Daily outputs of feces, urine, and manure are shown in Table 1. Fecal excretion was not different between treatments. However, urine excretion was lower (27.7 vs. $31.3 \mathrm{~kg} / \mathrm{d} ; P=0.02)$ for DG compared with CON. Manure production was not different between treatments. Despite a significant decrease in urine output for DG versus CON, the ratio of feces to urine did not differ $(P=0.11)$ between treatments.

Feeding the DG diet tended to decrease (6.41 vs. 6.66; $P=0.09$ ) fecal $\mathrm{pH}$ (Table 2). Dry matter content and $\mathrm{N}$ concentration on an as-is basis did not differ between CON and DG. However, N concentration in feces tended to be lower (24.5 vs. $25.5 \mathrm{~g} / \mathrm{kg}$ of DM; $P$ $=0.05)$ for $\mathrm{DG}$ versus CON manure when expressed on a DM basis. Cows fed the DG diet had greater $(P$ $<0.01) \mathrm{S}$ excretion in feces. Cows fed the DG diet had lower urine $\mathrm{pH}(7.48$ vs. $8.54 ; P<0.01)$ and greater $(P$
$<0.01) \mathrm{S}$ concentrations in urine compared with CON. However, $\mathrm{N}$ concentration in urine was not affected by DG versus CON. According to the differences in fecal and urine composition and excretion rates between CON and DG, manure composition was also altered. Manure $\mathrm{N}$ and $\mathrm{S}$ concentrations were lower (either DM basis or as-is basis; $P<0.01$ ) for DG versus CON. However, TS and VS of manure were not affected $(P \geq$ 0.12 ) by dietary treatments.

During the 10-d manure incubation, the rate of $\mathrm{NH}_{3}$ emission had an interaction of diet by day $(P<0.01$; Table 3). Cumulative $\mathrm{NH}_{3}$ production was lower (27.5 vs. $46.1 \mathrm{~g} /$ cow; $P<0.01$ ) for DG versus CON (Figure $1)$. Cows fed the DG diet versus CON had greater $(P \leq$ 0.03) $\mathrm{H}_{2} \mathrm{~S}$ emission rates and cumulative $\mathrm{H}_{2} \mathrm{~S}$ emissions from manure over $10 \mathrm{~d}$ (Figure 2).

Manure characteristics after the 10-d incubation were also different between treatments (Table 4). Manure $\mathrm{pH}$ was lower ( 7.24 vs. $7.47 ; P=0.02$ ) for DG versus CON. The content of VS was greater $(P<0.01)$ for DG versus CON, without a difference in TS. The concentrations of $\mathrm{N}$ and $\mathrm{S}$ in manure on a DM basis were greater $(P<$ 0.01) for DG compared with CON.

\section{DISCUSSION}

Although manure is valuable fertilizer, it may affect the environment (odor and air, soil, and water quality; NRC, 2003) in dairy production. The environmental impacts of manure can be largely reduced via good manure management (e.g., manure application rates, manure application method; Montes et al., 2013). However, various gases (e.g., $\mathrm{NH}_{3}$, greenhouse gases, and $\mathrm{H}_{2} \mathrm{~S}$ ) are produced from manure via microbial fermentation or chemical changes that may cause farm odor and a decrease in air quality at stalls and during

Table 1. Effects of feeding a diet containing high corn distillers grain on fecal, urine, and manure outputs ( $\mathrm{n}=9$ per treatment)

\begin{tabular}{|c|c|c|c|c|}
\hline \multirow[b]{2}{*}{ Item } & \multicolumn{2}{|c|}{ Diet $^{1}$} & \multirow[b]{2}{*}{ SEM } & \multirow[b]{2}{*}{$P$-value } \\
\hline & $\mathrm{CON}$ & DG & & \\
\hline $\mathrm{BW}, \mathrm{kg}$ & 721 & 757 & 21.2 & 0.23 \\
\hline Feces, ${ }^{2} \mathrm{~kg}$ of $\mathrm{DM} / \mathrm{d}$ & 7.5 & 7.7 & 0.36 & 0.69 \\
\hline Feces, $\mathrm{kg} / \mathrm{d}$ as is & 50.8 & 51.4 & 2.51 & 0.86 \\
\hline Urine, ${ }^{3} \mathrm{~kg} / \mathrm{d}$ & 31.3 & 27.7 & 1.59 & 0.02 \\
\hline Manure, $\mathrm{kg} / \mathrm{d}$ as is & 82.1 & 79.1 & 3.33 & 0.42 \\
\hline Feces:urine & 1.64 & 1.90 & 0.106 & 0.11 \\
\hline
\end{tabular}

${ }^{1} \mathrm{CON}=$ manure from cows fed a basal diet containing soybean meal; $\mathrm{DG}=$ manure from cows fed the control diet with $28.8 \%$ corn distillers grains with solubles (DM basis) replacing mainly soybean meal and soyhulls.

${ }^{2}$ Estimated for individual cows using indigestible NDF content in feeds and feces.

${ }^{3}$ Estimated for individual cows using urine creatinine concentration. 
Table 2. Effects of feeding a diet containing high corn distillers grain on fecal, urine, and manure characteristics on $\mathrm{d} 0(\mathrm{n}=9$ per treatment $)$

\begin{tabular}{|c|c|c|c|c|}
\hline \multirow[b]{2}{*}{ Item } & \multicolumn{2}{|c|}{$\operatorname{Diet}^{1}$} & \multirow[b]{2}{*}{ SEM } & \multirow[b]{2}{*}{$P$-value } \\
\hline & $\mathrm{CON}$ & DG & & \\
\hline \multicolumn{5}{|l|}{ Feces } \\
\hline $\mathrm{pH}$ & 6.66 & 6.41 & 0.092 & 0.09 \\
\hline $\mathrm{DM}, \mathrm{g} / \mathrm{kg}$ & 14.8 & 15.0 & 0.19 & 0.26 \\
\hline $\mathrm{N}, \mathrm{g} / \mathrm{kg}$ as is & 3.77 & 3.68 & 0.079 & 0.34 \\
\hline $\mathrm{N}, \mathrm{g} / \mathrm{kg}$ of $\mathrm{DM}$ & 25.5 & 24.5 & 0.34 & 0.05 \\
\hline $\mathrm{N}, \mathrm{g} / \mathrm{d}$ & 190.4 & 187.8 & 7.09 & 0.80 \\
\hline $\mathrm{S}, \mathrm{g} / \mathrm{kg}$ as is & 0.37 & 0.45 & 0.013 & $<0.01$ \\
\hline $\mathrm{S}, \mathrm{g} / \mathrm{kg}$ of $\mathrm{DM}$ & 2.51 & 2.99 & 0.08 & $<0.01$ \\
\hline $\mathrm{S}, \mathrm{g} / \mathrm{d}$ & 18.7 & 22.9 & 0.98 & $<0.01$ \\
\hline \multicolumn{5}{|l|}{ Urine } \\
\hline $\mathrm{pH}$ & 8.53 & 7.48 & 0.125 & $<0.01$ \\
\hline $\mathrm{N}, \mathrm{g} / \mathrm{kg}$ & 9.31 & 8.62 & 0.648 & 0.31 \\
\hline $\mathrm{N}, \mathrm{g} / \mathrm{d}$ & 287.2 & 231.4 & 12.72 & $<0.01$ \\
\hline $\mathrm{S}, \mathrm{g} / \mathrm{kg}$ & 0.64 & 2.15 & 0.081 & $<0.01$ \\
\hline $\mathrm{S}, \mathrm{g} / \mathrm{d}$ & 20.0 & 58.3 & 1.90 & $<0.01$ \\
\hline \multicolumn{5}{|l|}{ Manure } \\
\hline $\mathrm{TS}^{2} \mathrm{~g} / \mathrm{kg}$ & 110.3 & 116.3 & 2.59 & 0.12 \\
\hline $\mathrm{VS},{ }^{3} \mathrm{~g} / \mathrm{kg}$ & 865.3 & 870.3 & 3.01 & 0.25 \\
\hline $\mathrm{N}, \mathrm{g} / \mathrm{kg}$ as is & 5.86 & 5.34 & 0.212 & $<0.01$ \\
\hline $\mathrm{N}, \mathrm{g} / \mathrm{kg}$ of $\mathrm{DM}$ & 51.8 & 44.5 & 1.85 & $<0.01$ \\
\hline $\mathrm{N}, \mathrm{g} / \mathrm{d}$ & 477.6 & 419.2 & 15.8 & 0.02 \\
\hline Fecal N contribution, \% & 40.5 & 45.3 & 1.46 & $<0.01$ \\
\hline Urine $\mathrm{N}$ contribution, \% & 60.5 & 55.5 & 1.172 & $<0.01$ \\
\hline $\mathrm{S}, \mathrm{g} / \mathrm{kg}$ as is & 0.47 & 1.03 & 0.022 & $<0.01$ \\
\hline $\mathrm{S}, \mathrm{g} / \mathrm{kg}$ of $\mathrm{DM}$ & 4.31 & 8.87 & 0.175 & $<0.01$ \\
\hline $\mathrm{S}, \mathrm{g} / \mathrm{d}$ & 38.7 & 81.3 & 2.45 & $<0.01$ \\
\hline Fecal S contribution, $\%$ & 48.5 & 28.3 & 1.20 & $<0.01$ \\
\hline Urine $\mathrm{S}$ contribution, $\%$ & 51.5 & 71.7 & 1.20 & $<0.01$ \\
\hline
\end{tabular}

${ }^{1} \mathrm{CON}=$ manure from cows fed a basal diet containing soybean meal; DG $=$ manure from cows fed the control diet with $28.8 \%$ corn distillers grains with solubles (DM basis) replacing mainly soybean meal and soyhulls.

${ }^{2}$ Dry matter of manure.

${ }^{3}$ Volatile solids (OM of manure DM).

manure storage before manure application to the field (Fangueiro et al., 2015). The degree of gas emissions from manure is dependent on internal and external factors. The external factor could be temperature, humidity, wind, bedding, manure storage system, and so on. The internal factor is manure characteristics (i.e., manure volume, nutrient concentration, and chemical forms of nutrients). The manure characteristics can be altered by dietary nutritional composition. In the current study, therefore, a high-DG diet (28.8\% DDGS in dietary DM) was evaluated for changes in manure characteristics and potential gas emissions from manure. However, the data of gas emissions should be interpreted with caution because manure was incubated in a laboratory in vitro system, which is appropriate to identify relative differences between treatments but is

Table 3. Effects of feeding a diet containing high corn distillers grain on ammonia and hydrogen sulfide emissions from manure over $10 \mathrm{~d}^{1}(\mathrm{n}=9$ per treatment)

\begin{tabular}{|c|c|c|c|c|c|}
\hline \multirow[b]{2}{*}{ Item } & \multicolumn{2}{|c|}{ Diet $^{2}$} & \multirow[b]{2}{*}{ SEM } & \multicolumn{2}{|c|}{$P$-value ${ }^{3}$} \\
\hline & $\mathrm{CON}$ & DG & & Diet & Int \\
\hline $\mathrm{NH}_{3}, \mathrm{~g} /$ cow per $\mathrm{h}$ & 0.19 & 0.11 & 0.007 & $<0.01$ & $<0.01$ \\
\hline Cumulative $\mathrm{NH}_{3}, \mathrm{~g} / \mathrm{cow}$ & 46.1 & 27.5 & 1.58 & $<0.01$ & \\
\hline $\mathrm{H}_{2} \mathrm{~S}, \mathrm{mg} /$ cow per $\mathrm{h}$ & 2.06 & 3.43 & 0.438 & 0.03 & 0.46 \\
\hline Cumulative $\mathrm{H}_{2} \mathrm{~S}, \mathrm{mg} / \mathrm{cow}$ & 499.0 & 828.1 & 94.8 & $<0.01$ & \\
\hline
\end{tabular}

${ }^{1}$ Daily gas emissions measured were multiplied by total daily excretion of manure for emission data on a head basis.

${ }^{2} \mathrm{CON}=$ manure from cows fed a basal diet containing soybean meal; DG = manure from cows fed the control diet with $28.8 \%$ corn distillers grains with solubles (DM basis) replacing mainly soybean meal and soyhulls.

${ }^{3}$ Diet $=$ diet effect $(\mathrm{CON}$ vs. DG); Int $=$ interaction of diet by time $($ diet $\times$ time $)$. 
not indicative of actual emissions of gases from manure at farms.

Although feeding the DG diet to dairy cows did not alter the total amount of manure production compared with the CON diet, a significant decrease in urine output was observed. Changes in urine output by DG are not well studied in dairy cows. In beef cattle studies, the opposite results were found where increasing proportion of DG in a ration significantly increased urinary outputs (Salim et al., 2012; Li et al., 2014). However, in beef cattle studies, the DG diet usually increased dietary $\mathrm{CP}$ content compared with $\mathrm{CON}$ (i.e., treatment diets were not isonitrogenous). For example, Salim et al. (2012) increased proportion of corn distillers grains with solubles from 0 to $50 \%$ (DM basis),
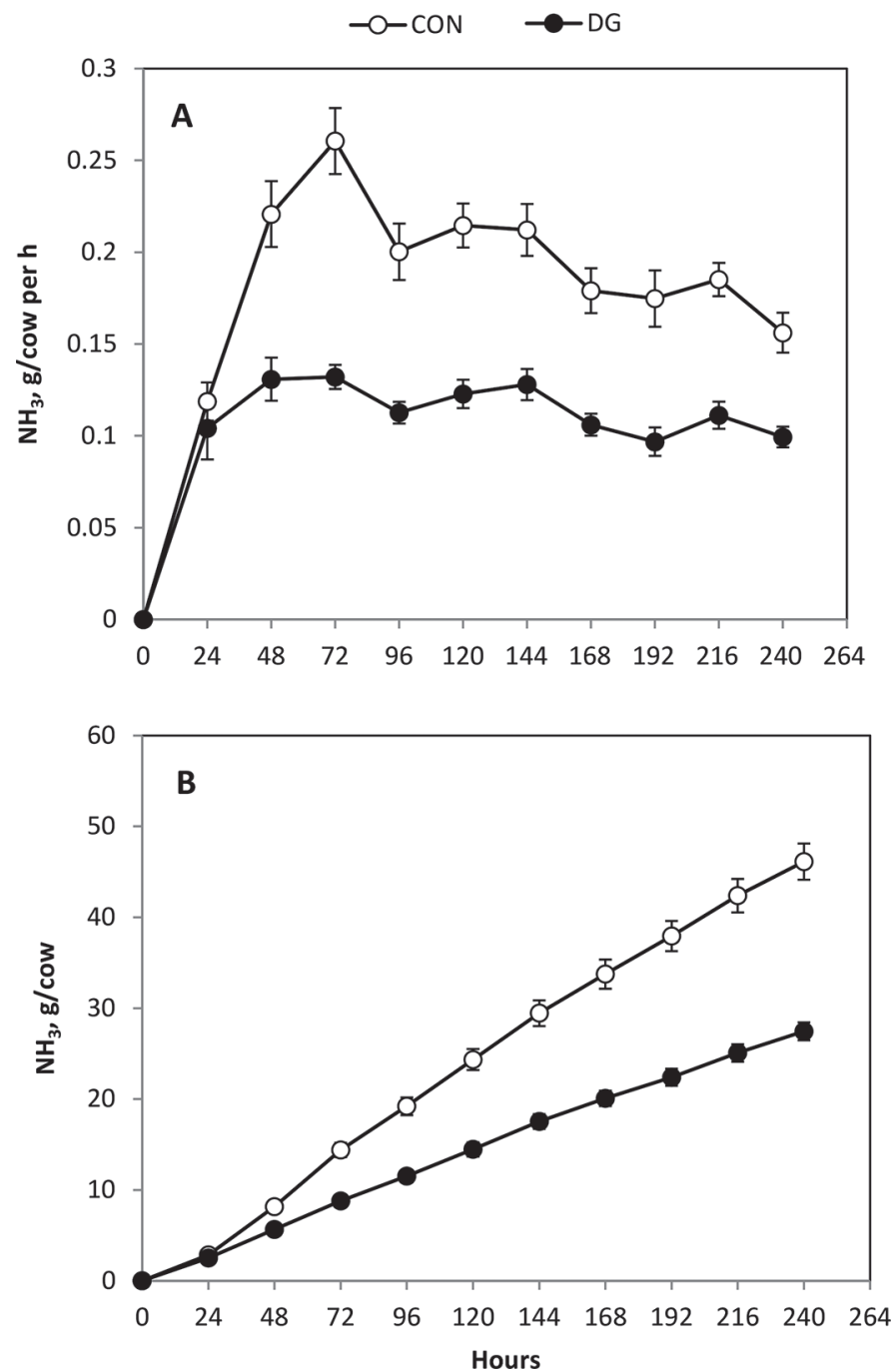

Figure 1. Ammonia emission rate (A; g/cow per hour; diet, $P<$ 0.01 ; diet $\times$ hour, $P<0.01)$ and cumulative ammonia emission $(\mathrm{B} ; \mathrm{g} /$ cow; diet, $P<0.01)$ from manure of cows fed the control diet $(\mathrm{CON})$ or the diet containing $28.8 \%$ corn distillers grain (DG). Error bars indicate SE. which increased dietary CP from 13.3 to $20.6 \%$ (DM basis). Because dietary CP concentration affects urine outputs (Broderick, 2003), the elevation of dietary CP with inclusion of DDGS was probably the factor that increased urine output, not DG per se, in beef studies. In the current study, dietary $\mathrm{CP}$ concentration was not different between CON and DG, but the DG diet had lower RDP and greater RUP concentrations compared with CON, which decreased plasma urea $\mathrm{N}$ and MUN concentrations (Morris et al., 2018b). Because MUN is one of the factors that alters urine excretion (Nennich et al., 2006), the lower RDP for the DG diet versus CON likely reduced urine outputs. As a result, daily urinary $\mathrm{N}$ excretion was lower for DG versus CON, and
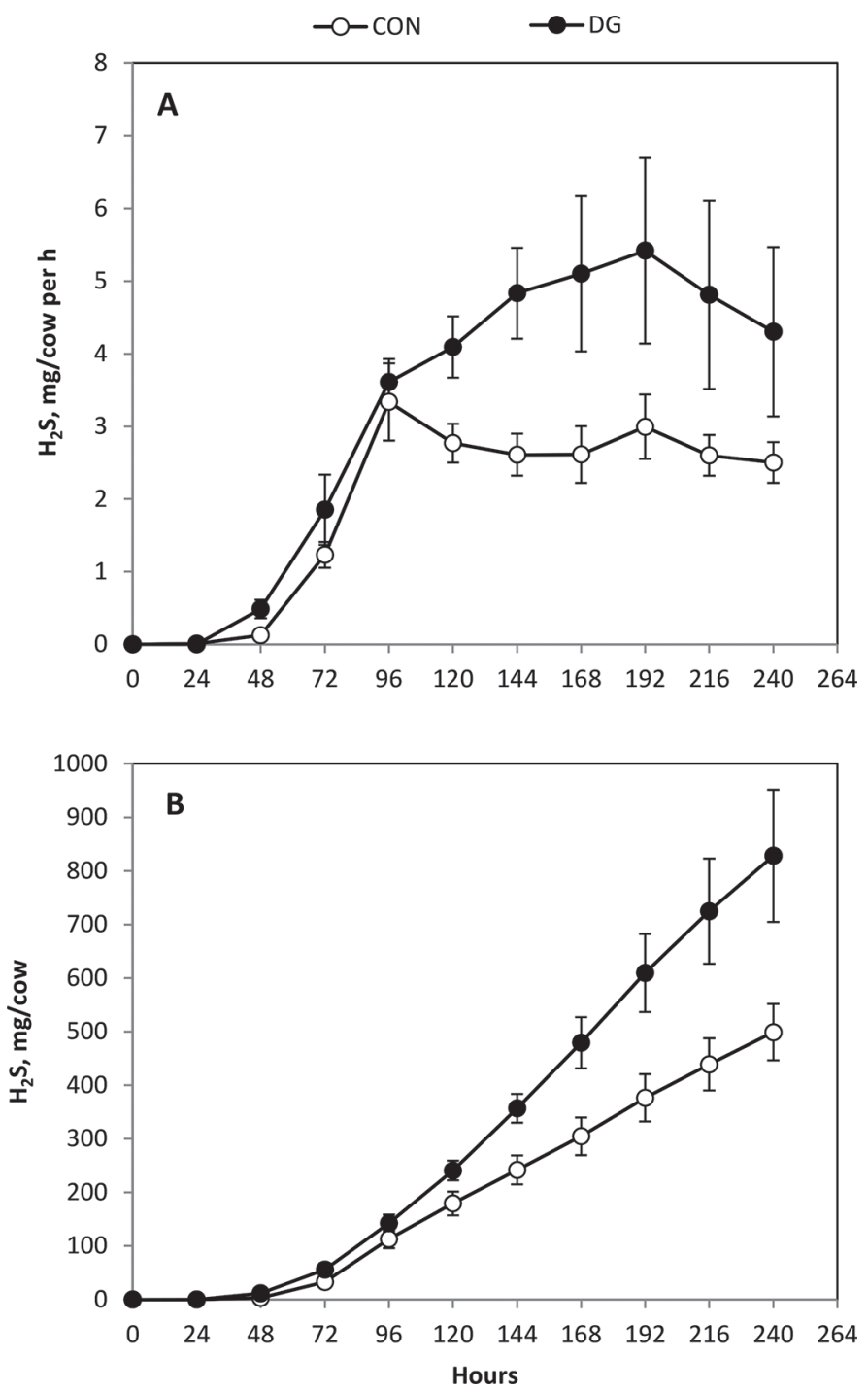

Figure 2. Hydrogen sulfide emission rate $(\mathrm{A} ; \mathrm{mg} / \mathrm{cow}$ per hour; diet, $P=0.03$; diet $\times$ hour, $P=0.46)$ and cumulative hydrogen sulfide emission (B; mg/cow; diet, $P<0.01$ ) from manure of cows fed the control diet $(\mathrm{CON})$ or the diet containing $28.8 \%$ corn distillers grain (DG). Error bars indicate SE. 
this could be a factor that potentially lowers $\mathrm{NH}_{3}$ emissions from manure (see the discussion later) because manure $\mathrm{N}$ that originated from urine is the main chemical form of $\mathrm{N}$ (i.e., urea) contributing to $\mathrm{NH}_{3}$ emitted from manure (Lee et al., 2011).

Manure $\mathrm{N}$ concentration was lower for $\mathrm{DG}$ versus CON, which occurred because urinary $\mathrm{N}$ concentration to manure was lower for DG versus CON. A potential shift of dietary $\mathrm{N}$ from urine to feces was reported when beef cattle were fed a DG diet compared with CON (Cole et al., 2008). In agreement, we observed about $5 \%$ units of $\mathrm{N}$ shift from urine to feces. This occurred due to decreased urinary $\mathrm{N}$ excretion for $\mathrm{DG}$ versus CON with no difference in fecal $\mathrm{N}$ excretion. Previously, Hristov et al. (2011) speculated that inclusion of DDGS in a ration can cause the shift of $\mathrm{N}$ and this shift can decrease $\mathrm{NH}_{3}$ emission from manure.

Inclusion of DDGS generally increases dietary S concentration due to high S content of DDGS. Therefore, as expected, the DG diet considerably increased $\mathrm{S}$ excretion in feces and urine. When dietary $\mathrm{S}$ concentration was normal (about $0.2 \%$ in dietary DM, i.e., the CON diet in the current study), the rate of $\mathrm{S}$ excretion was similar between feces and urine, which is in agreement with a previous beef study (Li et al., 2014). This beef study also observed that an increase in dietary $\mathrm{S}$ concentration by increasing the proportion of DG in a diet increased S excretion via urine and an increase in $\mathrm{S}$ excretion via feces was minimal. We observed similar results about $\mathrm{S}$ excretion between feces and urine for the DG diet compared with CON. This resulted in significant contribution of urinary $\mathrm{S}$ to manure $\mathrm{S}$. Although the major chemical form of $\mathrm{S}$ in urine and feces was not measured in the current study, it is expected to be sulfate (Hou et al., 2003) and organic S (microbes and feed residual) for urinary and fecal S,

Table 4. Effects of feeding a diet containing high corn distillers grain on manure characteristics on $\mathrm{d} 10(\mathrm{n}=9$ per treatment)

\begin{tabular}{lcclr}
\hline & \multicolumn{3}{c}{ Diet $^{1}$} & \\
\cline { 2 - 3 } Item & CON & DG & SEM & $P$-value \\
\hline $\mathrm{pH}$ & 7.47 & 7.24 & 0.096 & 0.02 \\
$\mathrm{TS},{ }^{2} \mathrm{~g} / \mathrm{kg}$ & 135.7 & 135.0 & 4.72 & 0.92 \\
$\mathrm{VS},{ }^{3} \mathrm{~g} / \mathrm{kg}$ & 843.0 & 855.1 & 2.57 & $<0.01$ \\
$\mathrm{~N}, \mathrm{~g} / \mathrm{kg}$ as is & 3.99 & 4.27 & 0.096 & 0.06 \\
$\mathrm{~N}, \mathrm{~g} / \mathrm{kg}$ of DM & 29.6 & 31.8 & 0.71 & $<0.01$ \\
$\mathrm{~S}, \mathrm{~g} / \mathrm{kg}$ as is & 0.62 & 1.29 & 0.051 & $<0.01$ \\
$\mathrm{~S}, \mathrm{~g} / \mathrm{kg}$ of DM & 4.59 & 9.51 & 0.197 & $<0.01$ \\
\hline
\end{tabular}

${ }^{1} \mathrm{CON}=$ manure from cows fed a basal diet containing soybean meal; $\mathrm{DG}=$ manure from cows fed the control diet with $28.8 \%$ corn distillers grains with solubles (DM basis) replacing mainly soybean meal and soyhulls.

${ }^{2}$ Dry matter of manure.

${ }^{3}$ Volatile solids (OM of manure DM). respectively. If this was the case, the increase in urinary $\mathrm{S}$ contribution to manure $\mathrm{S}$ could increase $\mathrm{H}_{2} \mathrm{~S}$ emission from manure via microbial reduction of sulfate to $\mathrm{H}_{2} \mathrm{~S}$ (Yokoyama et al., 2016).

Fecal $\mathrm{pH}$ also tended to be lower for DG versus CON, but the difference was relatively small. However, the large reduction in urine $\mathrm{pH}$ was not expected in the current study (see more discussion later), and no information about the effects of feeding a DG diet on urine $\mathrm{pH}$ in dairy cows is available to our knowledge. Actually, a large decrease in fecal $\mathrm{pH}$ was initially speculated, resulting in low manure $\mathrm{pH}$, when ruminants are fed a high-DG diet (Hristov et al., 2011). This speculation was made because of $\mathrm{H}_{2} \mathrm{SO}_{4}$ being added during DDGS production to control $\mathrm{pH}$ and cleanup, increasing acidity of DDGS. Therefore, high inclusion of DDGS in a ration can lower rumen $\mathrm{pH}$ (Castillo-Lopez et al., 2014; Ramirez-Ramirez et al., 2016), which could lower fecal $\mathrm{pH}$. However, a tendency of the small reduction in fecal $\mathrm{pH}$ for DG in the current study may indicate that a change in fecal $\mathrm{pH}$ by the $\mathrm{DG}$ diet is minimal in spite of reduced rumen $\mathrm{pH}$. The decrease in urine $\mathrm{pH}$ for DG versus CON was significant, and this was another factor that lowers $\mathrm{NH}_{3}$ emissions from DG manure.

The ammonia emission rate ( $\mathrm{g} / \mathrm{cow}$ per $\mathrm{h}$ ) and cumulative $\mathrm{NH}_{3}$ emission (g/d) was about $40 \%$ lower for DG versus $\mathrm{CON}$. The degree of the decrease in $\mathrm{NH}_{3}$ emissions by DG in this study is similar to the decrease observed when feeding a low protein diet, which is probably one of the best nutritional strategies to lower $\mathrm{NH}_{3}$ emission from manure in dairy cows (Hristov et al., 2011). Previously, a reduction of dietary CP from 16 to $14 \%$ of dietary DM decreased $\mathrm{NH}_{3}$ emission from manure by about $40 \%$ (Lee et al., 2012a,b). Therefore, feeding the DG diet (about 30\% DDGS in dietary DM) was as effective in lowering ammonia emission from manure as feeding a lower protein diet. The lower $\mathrm{NH}_{3}$ emission from manure for DG can be explained by 2 factors. As discussed earlier, feeding the DG diet altered the route of $\mathrm{N}$ excretion from urine to feces compared with $\mathrm{CON}$, which occurred when the CON and DG diets were isonitrogenous. Therefore, the contribution of urine $\mathrm{N}$ to manure $\mathrm{N}$ changed from 60.5 to $55.5 \%$, which resulted in decreases in the contribution of urinary $\mathrm{N}$ to manure $\mathrm{N}$ by $19 \%$ and decreases in total manure $\mathrm{N}$ by $12 \%$ for DG compared with CON. In other words, $\mathrm{N}$ excretion was about $58.4 \mathrm{~g} / \mathrm{d}$ less for DG versus CON manure and $96 \%$ of the lower $\mathrm{N}$ excretion $(55.8 \mathrm{~g} / \mathrm{d})$ was due to decreased urinary N. In addition, proportion of urea-N in total urinary $\mathrm{N}$ was about 65 to $70 \%$ (data shown in Morris et al., 2018b), meaning that urea $\mathrm{N}$ in DG manure was about $36 \mathrm{~g} / \mathrm{d}$ less than in CON manure. Because urea is the form of $\mathrm{N}$ that is rapidly converted to $\mathrm{NH}_{3}$ in manure during a short-term manure incuba- 
tion (Lee et al., 2011), the shift of dietary N excretion from urine to feces for DG versus CON likely explains the $40 \%$ decrease in $\mathrm{NH}_{3}$ emission (i.e., DG manure vs. $\mathrm{CON}$ had $15 \mathrm{~g}$ less $\mathrm{NH}_{3}-\mathrm{N}$ volatilized over $10 \mathrm{~d}$ ).

Another factor that decreased $\mathrm{NH}_{3}$ emission from manure for $\mathrm{DG}$ was lower urine $\mathrm{pH}$ compared with $\mathrm{CON}$. This may have caused manure $\mathrm{pH}$ to be lower for DG versus CON. Accidently, we did not measure manure $\mathrm{pH}$ on $\mathrm{d} 0$ of the incubation, but the lower manure $\mathrm{pH}$ likely occurred according to lower manure $\mathrm{pH}$ at $\mathrm{d} 10$ and greater manure $\mathrm{N}$ concentration for DG versus CON (see more discussion later). Although the contribution cannot be quantified in the current study, it is possible that the reduced urine $\mathrm{pH}$ for DG decreased $\mathrm{NH}_{3}$ emissions from manure. Acidification of manure is an effective management strategy to lower gas emissions, especially $\mathrm{NH}_{3}$ emission (Sommer et al., 2017). However, acidification of manure in commercial farms is limited because highly concentrated acid (e.g., $\mathrm{H}_{2} \mathrm{SO}_{4}$ ) needs to be handled by a specialized worker and is dangerous, increasing the cost for manure management. Therefore, reducing manure $\mathrm{pH}$ by feeding a diet containing DDGS can be a potential strategy to lower $\mathrm{NH}_{3}$ emissions from manure that can be immediately applied in practice. Why, then, did the DG diet decrease urine $\mathrm{pH}$ ? The decrease in urine $\mathrm{pH}$ occurred because of high $\mathrm{S}$ concentration in the DG diet due to high inclusion of DDGS. Sulfur concentration in DDGS is high and varies from 0.7 to $1.2 \%$ (DM basis; DuFour, 2017). Therefore, inclusion of DG in a ration resulted in an increase in dietary $\mathrm{S}$ greater than the typical $\mathrm{S}$ level $(0.2 \%$ in dietary $\mathrm{DM})$. Because of the high $\mathrm{S}$ concentration, DCAD $(\mathrm{Na}+\mathrm{K}-\mathrm{Cl}-\mathrm{S})$ in the DG diet decreased from 192 to $65 \mathrm{mEq} / \mathrm{kg}$ of DM in the current study (data shown in Morris et al., 2018a). The urine $\mathrm{pH}$ of 7.48 with the reduced DCAD $(65 \mathrm{mEq} / \mathrm{kg}$ of $\mathrm{DM})$ of the DG diet is in agreement with a meta-analysis by Santos et al. (2019), where changes in urine $\mathrm{pH}$ by various DCAD in dry cows are shown. Feeding a negative DCAD diet reduces urine pH (acid-base homeostasis; Santos et al., 2019), and this is a well-established strategy for prepartum cows to improve health (e.g., hypocalcemia) and production of cows after parturition (Lean et al., 2019; Santos et al., 2019). After parturition, however, DCAD should be positive, and low DCAD can negatively affect DMI, milk yield and composition, and feed digestibility (Iwaniuk and Erdman, 2015). In our study, we observed that the DG diet decreased DMI, ECM, and milk fat and protein yields compared with CON (Morris et al., 2018a). Negative DMI and production responses (especially milk fat depression; Ramirez-Ramirez et al., 2016) to feeding a DG diet have been often explained by high PUFA supply. However, we suggest that the negative DMI and production effects by a DG diet need to be reevaluated where reduced DCAD in addition to high PUFA supply may have been responsible.

The DG diet (about 30\% DG on a DM basis) in the current study may not be an ideal nutritional strategy in practice, although it decreased $\mathrm{NH}_{3}$ emission from manure by $40 \%$. First, the DG diet decreased production of cows as mentioned previously. Therefore, to fix this issue, more studies are needed to examine lower DG inclusion rates in a ration but at an inclusion rate that is sufficient to decrease $\mathrm{NH}_{3}$ emission from manure. Second, the DG diet increased $\mathrm{H}_{2} \mathrm{~S}$ emission from manure. In the current study, the $\mathrm{H}_{2} \mathrm{~S}$ emission rate and accumulated $\mathrm{H}_{2} \mathrm{~S}$ emission over $10 \mathrm{~d}$ of incubation increased by about $67 \%$ for the DG diet versus CON. It is likely that feeding the DG diet resulted in increases in $\mathrm{H}_{2} \mathrm{~S}$ emission from manure because of increased dietary $\mathrm{S}$ concentration and $\mathrm{S}$ intake of cows, which resulted in increases in $\mathrm{S}$ concentration in manure ( $\mathrm{Li}$ et al., 2014; Morris et al., 2018b). In addition, as discussed earlier, the DG diet reduced urine $\mathrm{pH}$ (then probably manure $\mathrm{pH}$ ), and the form of $\mathrm{S}$ in manure can become more volatile $\left(\mathrm{p} K_{\mathrm{a}}\right.$ of $\left.\mathrm{H}_{2} \mathrm{~S}=7.0\right)$ at relatively low $\mathrm{pH}$ (Fangueiro et al., 2015). However, when $\mathrm{H}_{2} \mathrm{~S}$ emissions from manure were measured after feeding a DG diet in previous studies, results were quite variable in pigs (no dairy and beef cattle data are available, to our knowledge). In agreement with our results, Powers et al. (2009) observed $\mathrm{H}_{2} \mathrm{~S}$ emissions from manure of pigs fed a $20 \%$ DG diet where $\mathrm{H}_{2} \mathrm{~S}$ emission was greater for the DG diet versus CON, although the difference in dietary $\mathrm{S}$ concentration between $\mathrm{CON}$ and the DG diet in this study was small (0.19 and $0.20 \%$ in dietary DM, respectively). Spiehs et al. (2012) observed no differences in $\mathrm{H}_{2} \mathrm{~S}$ concentration in air of the simulated manure deep pit when manure of pigs fed a 20\% DG diet (DM basis) compared with CON was incubated. In the study by Spiehs et al. (2012), the calculated dietary $\mathrm{S}$ concentration was 0.18 and $0.24 \%$ for CON and the DG diet in this study. However, this study observed high variation for $\mathrm{H}_{2} \mathrm{~S}$ measurements (CV of $49.5 \%$ ), which may have masked treatment effects. In addition, although manure outputs were greater for the DG diet versus CON in the study by Spiehs et al. (2012), this was not considered when $\mathrm{H}_{2} \mathrm{~S}$ emission from manure was compared between treatments and only $\mathrm{H}_{2} \mathrm{~S}$ concentration measured in air was reported. Trabue et al. (2016), in contrast to our results, observed a decrease in $\mathrm{H}_{2} \mathrm{~S}$ emitted from manure $(0.87$ vs. $1.80 \mathrm{~g} / \mathrm{d}$ per animal) of pigs fed a DG diet (35\% on a DM basis) versus CON. However, manure characteristics (e.g., low manure $\mathrm{pH}$ and high $\mathrm{S}$ concentration in manure) indicated that DG manure would have potential to have more $\mathrm{H}_{2} \mathrm{~S}$ production. In the study by Trabue et 
al. (2016), this discrepancy was explained by crusting of manure (i.e., crusting of manure reduces $\mathrm{H}_{2} \mathrm{~S}$ emissions). In the current study, we also observed formation of crust on the surface of all manures, and we found no visual difference in crusting between CON and DG. This is supported by no difference in TS measured after the 10-d incubation. The content of VS was statistically different, but the difference was only $1.4 \%$ greater for DG versus CON. However, existence of the crust may have affected $\mathrm{H}_{2} \mathrm{~S}$ emissions to some degree in the current study because we observed greater variability of $\mathrm{H}_{2} \mathrm{~S}$ production within DG manures compared with CON manures (see Figure 2). Producing $\mathrm{H}_{2} \mathrm{~S}$ from manure was a relatively slower process compared with $\mathrm{NH}_{3}$ emission according to gradual increases in $\mathrm{H}_{2} \mathrm{~S}$ emission over days of the incubation (the interaction of treatment by time). As described previously, if sulfate was the major source for $\mathrm{H}_{2} \mathrm{~S}$ emitted from manure, sulfate should be reduced to $\mathrm{H}_{2} \mathrm{~S}$ by manure microbes, which could be a time-requiring process.

Manure $\mathrm{N}$ and $\mathrm{S}$ concentrations after the 10-d incubation were greater for DG versus CON. This supports the considerable reduction in $\mathrm{NH}_{3}$ emissions from DG manure compared with CON. Manure S concentration did not change much over $10 \mathrm{~d}$ because $\mathrm{S}$ lost from manure via $\mathrm{H}_{2} \mathrm{~S}$ production was only $1 \%$ of total $\mathrm{S}$ in manure for both CON and DG. This indicates that $\mathrm{H}_{2} \mathrm{~S}$ emission from manure occurs in the long term, and a long-term incubation of manure to measure $\mathrm{H}_{2} \mathrm{~S}$ production from manure is necessary.

\section{CONCLUSIONS}

Inclusion of DG in a ration at $28.8 \%$ on a DM basis compared with a SBM-based diet (CON) decreased urine output and urinary $\mathrm{N}$ excretion without affecting fecal output and fecal $\mathrm{N}$ excretion. This resulted in low manure $\mathrm{N}$ concentration and reduced urinary $\mathrm{N}$ contribution to manure $\mathrm{N}$ for the $\mathrm{DG}$ diet versus CON. In addition, inclusion of DDGS in a ration reduced DCAD compared with CON due to high S content, which reduced urine $\mathrm{pH}$. Therefore, altering the route of $\mathrm{N}$ excretion and manure $\mathrm{pH}$ by feeding the $\mathrm{DG}$ diet considerably reduced $\mathrm{NH}_{3}$ emission from manure during the 10-d manure incubation. Because of high $\mathrm{S}$ content in DG, the DG diet increased dietary S content compared with the CON diet and increased fecal and urinary $\mathrm{S}$ excretion. Therefore, greater $\mathrm{S}$ concentration and lower $\mathrm{pH}$ for DG manure versus CON manure resulted in greater $\mathrm{H}_{2} \mathrm{~S}$ emission. More studies are needed to determine the optimum level of DG in a ration that reduces $\mathrm{NH}_{3}$ emissions from manure without negatively affecting DMI and production. A long-term incubation of manure will be necessary to understand $\mathrm{H}_{2} \mathrm{~S}$ emissions during manure storage.

\section{ACKNOWLEDGMENTS}

The project was supported with state and federal funds appropriated to the Ohio Agricultural Research and Development Center, The Ohio State University. The authors thank all staff at Krauss Dairy Research Center (Ohio Agricultural Research and Development Center, Wooster, $\mathrm{OH}$ ) for animal care. The authors have not stated any conflicts of interest.

\section{REFERENCES}

Aillery, M., N. Gollehon, R. Johansson, J. Kaplan, N. Key, and M. Ribaudo. 2005. Managing manure to improve air and water quality. Economic Research Report 9. USDA. Accessed Dec. 10, 2019. https: / / www.ers.usda.gov/publications/pub-details/?pubid= 46351.

AOAC International. 2000. Official Methods of Analysis. Vol. 1 and 2. 17th ed. AOAC Int., Gaithersburg, MD.

Benchaar, C., F. Hassanat, R. Gervais, P. Y. Chouinard, C. Julien, H. V. Petit, and D. I. Masse. 2013. Effects of increasing amounts of corn dried distillers grains with solubles in dairy cow diets on methane production, ruminal fermentation, digestion, $\mathrm{N}$ balance, and milk production. J. Dairy Sci. 96:2413-2427. https://doi.org/ 10.3168/jds.2012-6037.

Broderick, G. A. 2003. Effects of varying dietary protein and energy levels on the production of lactating dairy cows. J. Dairy Sci. 86:1370-1381. https://doi.org/10.3168/jds.S0022-0302(03)73721 $-7$.

Castillo-Lopez, E., H. A. Ramirez Ramirez, T. J. Klopfenstein, D. Hostetler, K. Karges, S. C. Fernando, and P. J. Kononoff. 2014. Ration formulations containing reduced-fat dried distillers grains with solubles and their effect on lactation performance, rumen fermentation, and intestinal flow of microbial nitrogen in Holstein cows. J. Dairy Sci. 97:1578-1593. https://doi.org/10.3168/jds.2013 -6865 .

Cole, N. A., M. S. Brown, and J. C. MacDonald. 2008. Environmental considerations of feeding bio-fuel co-products. J. Anim. Sci. 86(E. Suppl. 2):157. (Abstr.)

Costigan, M. G. 2003. Hydrogen sulfide: UK occupational exposure limits. Occup. Environ. Med. 60:308-312. https://doi.org/10 .1136/oem.60.4.308.

DuFour, E. I. 2017. Advancing chemical characterization of feedstuffs commonly included in dairy cow rations. MS Thesis. Univ. Nebraska, Lincoln, NE. Accessed Dec. 10, 2019. https://digitalcommons .unl.edu/animalscidiss/146.

Fangueiro, D., M. Hjorth, and F. Gioelli. 2015. Acidification of animal slurry-A review. J. Environ. Manage. 149:46-56. https://doi.org/ 10.1016/j.jenvman.2014.10.001.

Foth, A. J., T. Brown-Brandl, K. J. Hanford, P. S. Miller, G. Garcia Gomez, and P. J. Kononoff. 2015. Energy content of reduced-fat dried distillers grains with solubles for lactating dairy cows. J. Dairy Sci. 98:7142-7152. https://doi.org/10.3168/jds.2014-9226.

Hou, C. S., L. J. Wykes, and L. J. Hoffer. 2003. Urinary sulfur excretion and the nitrogen/sulfur balance ratio reveal nonprotein sulfur amino acid retention in piglets. J. Nutr. 133:766-772. https://doi .org/10.1093/jn/133.3.766.

Hristov, A. N., M. Hanigan, A. Cole, R. Todd, T. A. McAllister, P. M. Ndegwa, and A. Rotz. 2011. Review: Ammonia emissions from dairy farms and beef feedlots. Can. J. Anim. Sci. 91:1-35. https:/ /doi.org/10.4141/CJAS10034.

Huhtanen, P., K. Kaustell, and S. Jaakkola. 1994. The use of internal markers to predict total digestibility and duodenal flow of nutri- 
ents in cattle given six different diets. Anim. Feed Sci. Technol. 48:211-227. https://doi.org/10.1016/0377-8401(94)90173-2.

Isaac, R. A., and W. A. Johnson. 1985. Elemental analysis of plant tissue by plasma emission spectroscopy: Collaborative study. J. Assoc. Off. Anal. Chem. 68:499-505.

Iwaniuk, M. E., and R. A. Erdman. 2015. Intake, milk production, ruminal, and feed efficiency responses to dietary cation-anion difference by lactating dairy cows. J. Dairy Sci. 98:8973-8985. https: //doi.org/10.3168/jds.2015-9949.

Lean, I. J., J. E. P. Santos, E. Block, and H. M. Golder. 2019. Effects of prepartum dietary cation-anion difference intake on production and health of dairy cows: A meta-analysis. J. Dairy Sci. 102:21032133. https://doi.org/10.3168/jds.2018-14769.

Lee, C., A. N. Hristov, T. Cassidy, and K. Heyler. 2011. Nitrogen isotope fractionation and origin of ammonia nitrogen volatilized from cattle manure in simulated storage. Atmosphere (Basel) 2:256270. https://doi.org/10.3390/atmos2030256.

Lee, C., A. N. Hristov, C. J. Dell, G. W. Feyereisen, J. Kaye, and D. Beegle. 2012a. Effect of dietary protein concentration on ammonia and greenhouse gas emitting potential of dairy manure. J. Dairy Sci. 95:1930-1941. https://doi.org/10.3168/jds.2010-4141.

Lee, C., A. N. Hristov, K. S. Heyler, T. W. Cassidy, H. Lapierre, G. A. Varga, and C. Parys. 2012b. Effects of metabolizable protein supply and amino acid supplementation on nitrogen utilization, milk production, and ammonia emissions from manure in dairy cows. J. Dairy Sci. 95:5253-5268. https://doi.org/10.3168/jds.2012-5366.

Li, Y. L., K. A. Beauchemin, T. A. McAllister, and W. Z. Yang. 2014. Intakes and excretion route of nitrogen, phosphorous and sulfur by finishing beef heifers fed increasing levels of wheat dried distillers grains with solubles to substitute for barley grain and barley silage. Livest. Sci. 170:43-52. https://doi.org/10.1016/j.livsci.2014 .09.020.

Maxin, G., D. R. Ouellet, and H. Lapierre. 2013. Ruminal degradability of dry matter, crude protein, and amino acids in soybean meal, canola meal, corn, and wheat dried distillers grains. J. Dairy Sci. 96:5151-5160. https://doi.org/10.3168/jds.2012-6392.

Mjoun, K., K. F. Kalscheur, A. R. Hippen, and D. J. Schingoethe. 2010. Ruminal degradability and intestinal digestibility of protein and amino acids in soybean and corn distillers grains products. J. Dairy Sci. 93:4144-4154. https://doi.org/10.3168/jds.2009-2883.

Montes, F., R. Meinen, C. Dell, A. Rotz, A. N. Hristov, J. Oh, G. Waghorn, P. J. Gerber, B. Henderson, H. P. S. Makkar, and J. Dijkstra. 2013. Special Topics - Mitigation of methane and nitrous oxide emissions from animal operations: II. A review of manure management mitigation options. J. Anim. Sci. 91:5070-5094. https://doi.org/10.2527/jas.2013-6584.

Morris, D. L., S. H. Kim, P. J. Kononoff, and C. Lee. 2018a. Continuous 11-week feeding of reduced-fat distillers grains with and without monensin reduces lactation performance of dairy cows. J. Dairy Sci. 101:5971-5983. https://doi.org/10.3168/jds.2017-14170.

Morris, D. L., S. H. Kim, and C. Lee. 2018b. Effects of corn feeding reduced-fat distillers grains with or without monensin on nitrogen, phosphorus, and sulfur utilization and excretion in dairy cows. J. Dairy Sci. 101:7106-7116. https://doi.org/10.3168/jds.2018-14528.

Morris, D. L., A. W. Tebbe, W. P. Weiss, and C. Lee. 2019. Short communication: Effects of drying and analytical methods on nitrogen concentrations of feeds, feces, milk, and urine of dairy cows. J. Dairy Sci. 102:5212-5218. https://doi.org/10.3168/jds.2019-16256.

Nennich, T. D., J. H. Harrison, L. M. VanWieringen, N. R. St-Pierre, R. L. Kincaid, M. A. Wattiaux, D. L. Davidson, and E. Block. 2006. Prediction and evaluation of urine and urinary nitrogen and mineral excretion from dairy cattle. J. Dairy Sci. 89:353-364. https://doi.org/10.3168/jds.S0022-0302(06)72101-4.

NRC. 2003. Air Emissions from Animal Feeding Operations: Current Knowledge, Future Needs. Natl. Res. Counc., Natl. Acad. Press, Washington, DC.

Powers, W. J., W. Li, and G. Hill. 2009. Feeding DDGS to swine and resulting impact on air emissions. Pages 7-19 in Proc. Swine Nutr.
Conf., Indianapolis, IN. Midwest Swine Nutrition Conference, Indianapolis, IN.

Ramirez-Ramirez, H. A., E. Castillo Lopez, C. J. R. Jenkins, N. D. Aluthge, C. Anderson, S. C. Fernando, K. J. Harvatine, and P. J. Kononoff. 2016. Reduced-fat dried distillers grains with solubles reduces the risk for milk fat depression and supports milk production and ruminal fermentation in dairy cows. J. Dairy Sci. 99:1912-1928. https://doi.org/10.3168/jds.2015-9712.

Salim, H., K. M. Wood, M. K. Abo-Ismail, P. L. McEwen, I. B. Mandell, S. P. Miller, J. P. Cant, and K. C. Swanson. 2012. Influence of feeding increasing levels of dry corn distillers grains plus solubles in whole corn grain-based finishing diets on total tract digestion, nutrient balance, and excretion in beef steers. J. Anim. Sci. 90:4441-4448. https://doi.org/10.2527/jas.2011-4332.

Santos, J. E. P., I. J. Lean, H. Golder, and E. Block. 2019. Meta-analysis of the effects of prepartum dietary cation-anion difference on performance and health of dairy cows. J. Dairy Sci. 102:2134-2154. https://doi.org/10.3168/jds.2018-14628.

Schingoethe, D. J., K. F. Kalscheur, A. R. Hippen, and A. D. Garcia. 2009. Invited review: The use of distillers products in dairy cattle diets. J. Dairy Sci. 92:5802-5813. https://doi.org/10.3168/ jds.2009-2549.

Sommer, S. G., T. J. Clough, N. Balaine, S. D. Hafner, and K. C. Cameron. 2017. Transformation of organic matter and the emissions of methane and ammonia during storage of liquid manure as affected by acidification. J. Environ. Qual. 46:514-521. https://doi .org/10.2134/jeq2016.10.0409.

Spiehs, M. J., M. H. Whitney, G. C. Shurson, R. E. Nicolai, J. A. Renteria Flores, and D. B. Parker. 2012. Odor and gas emissions and nutrient excretion from pigs fed diets containing dried distillers grains with solubles. Appl. Eng. Agric. 28:431-437. https://doi .org/10.13031/2013.41492.

Tebbe, A. W., and W. P. Weiss. 2018. Evaluation of creatinine as a urine marker and factors affecting urinary excretion of magnesium by dairy cows. J. Dairy Sci. 101:5020-5032. https://doi.org/ $10.3168 /$ jds.2017-14098.

Trabue, S., B. Kerr, and K. Scoggin. 2016. Odor and odorous compound emissions from manure of swine fed standard and dried distillers grains with soluble supplemented diets. J. Environ. Qual. 45:915-923. https://doi.org/10.2134/jeq2015.10.0511.

Valadares, R. F. D., G. A. Broderick, S C. V. Filho, and M. K. Clayton. 1999. Effect of replacing alfalfa silage with high moisture corn on ruminal protein synthesis estimated from excretion of total purine derivatives. J. Dairy Sci. 82:2686-2696. https://doi.org/10 .3168/jds.S0022-0302(99)75525-6.

Van Baale, M. J., J. M. Sargeant, D. P. Gnad, B. M. DeBey, K. F. Lechtenberg, and T. G. Nagaraja. 2004. Effect of forage or grain diets with or without monensin on ruminal persistence and fecal Escherichia coli O157:H7 in cattle. Appl. Environ. Microbiol. 70:5336-5342. https://doi.org/10.1128/AEM.70.9.5336-5342.2004.

Wheeler, E. F., P. A. Topper, R. C. Brandt, N. E. Brown, A. Adviento-Borbe, R. S. Thomas, and G. A. Varga. 2011. Multiple-chamber instrumentation development for comparing gas fluxes from biological materials. Appl. Eng. Agric. 27:1049-1060. https://doi.org/ 10.13031/2013.40618.

Yokoyama, M. T., C. Spence, S. M. Hengemuehle, T. R. Whitehead, R. von Bernuth, and M. Cotta. 2016. Sodium tetraborate decahydrate treatment reduces hydrogen sulfide and the sulfate-reducing bacteria population of swine manure. J. Environ. Qual. 45:18381846. https://doi.org/10.2134/jeq2016.06.0219.

\section{ORCIDS}

C. Lee (ㄴ) https://orcid.org/0000-0002-4522-1232

D. L. Morris @ ittps://orcid.org/0000-0001-6347-2804

P. A. Dieter @ https://orcid.org/0000-0002-1152-7700 